\title{
Protection of economic rights in Eastern European countries
}

\author{
OLHA KULYNYCH $^{1}$, OKSANA KURYLINA ${ }^{2}$, NATALIIA SERDIUK ${ }^{3}$, SERHII BASHLAI ${ }^{4}$, \\ OLENA NESTERENKO ${ }^{5}$, PETRO TRACHUK ${ }^{6}$
}

\author{
${ }^{1}$ Department of Legal Ensuring Business Security, Kyiv National University of Trade and Economics, \\ Kyiv, UKRAINE \\ ${ }^{2}$ Scientific Research and Implementation of Innovation Technologies Department of the Building \\ Integrity Training and Research Centre, National Defense University of Ukraine named after Ivan \\ Cherniakhovskyi, Kyiv, UKRAINE \\ ${ }^{3}$ Department of Law, Kyiv National Linguistic University, Kyiv, UKRAINE \\ ${ }^{4}$ Department of Economics and Entrepreneurship, Sumy National Agrarian University, Sumy, \\ UKRAINE \\ ${ }^{5}$ Department of Economic Theory, Macro- and Microeconomics, Taras Shevchenko National \\ University of Kyiv, Kyiv, UKRAINE \\ ${ }^{6}$ Department of Administrative, Financial and Information Law, State University "Uzhhorod National \\ University", Uzhhorod, UKRAINE
}

\begin{abstract}
Current problems in the protection of economic rights in Eastern Europe (the impact of the oil industry on the environment and human health, discrimination in employment, including the abuse of the rights of migrant workers and women) determine the potential for economic development. This scientific article based on: qualitative and quantitative methodology; combination of comprehensive and systematic approaches; case method; analysis of statistical indicators. The aim of the research is to analyze the protection of economic rights in Eastern European countries and their negative impact on the lives of citizens. It has been found that in addition to unresolved issues of non-payment of salaries and discrimination against various social groups, these countries have new problems in the field of protection of intellectual property rights through the development of the digital economy. The legal system carefully and slowly integrates the practice of developed countries to provide guarantees for the most vulnerable (women, migrant workers). As a result, Eastern European countries are characterized by slow structural changes in the economy and an average level of GDP per capita. Discrimination, which is characterized by differences, is among the main problems. Discrimination does not ensure equal access for women to all spheres of public life. The revealed connection between gender equality and the economic wellbeing of the population proves the importance of protecting economic rights as a tool to ensure the formation of a socially oriented market economy. In Eastern European countries, there is no consistent concept of equality regardless of the social-economic characteristics of the citizen. Judicial practice remains quite cautious in sentencing and there are cases of return to formal equality.
\end{abstract}

Key-Words: - Economic Rights, Economic Policy, Protection of Property Rights, Protection of Intellectual Property Rights, European Union Court of Justice

Received: January 3, 2021. Revised: April 17, 2021. Accepted: April 28, 2021. Published: May 5, 2021.

\section{Introduction}

The principle of economic and social cohesion is one of the strongest defining features of $\mathrm{EU}$ in the framework of international economic and social models. This applies to fundamental human rights, which fully include economic and social rights. The duty of the state to protect human rights is fundamental, but quite often states do not have a clear understanding of the specific obligations to ensure the observance and protection of economic rights.

Human rights issues arise in every economic sphere, in particular, when it comes to corporate relations, the conclusion of investment agreements, trade agreements, the circulation of securities. At the same time, there is a negative impact of business transactions on human rights. Health and safety at work have been the key problems of business and human rights in Eastern Europe in recent years. The impact of a polluted environment on health, discrimination [1], labor rights violations [2; 3], including migrants, minorities, children and women [4], illegal migrants and their health protection [5], problems of social inequality [6] and poverty are also serious issues [7]. These are current challenges to be 
expected in the coming years in many countries. Eastern Europe has problems with the impact of the oil industry on the environment and human health, discrimination in employment, concerns about the possible negative consequences of shale gas production, abuse of the rights of migrant workers [4]. In this regard, it is necessary to investigate the issue of protecting economic rights and ensuring respect for human rights and their observance by business.

The purpose of the scientific article is to analyze the protection of economic rights in Eastern Europe countries and their negative impact on the lives of citizens.

Research objectives of the article are as follows:

1. to carry out a content analysis of international legislation and identify specific features (peculiarities) of economic rights of citizens;

2. to identify typical violations of economic rights that occur in Eastern European countries;

3. to carry out economic and factual analysis of violations of the right to an adequate standard of living; discrimination in the labor market; infringements of intellectual property rights; the impact of the polluted environment on human health in Eastern Europe.

\section{Literature Review}

\subsection{Approaches and issues}

Recent developments on the protection of economic human rights in Eastern Europe indicate its high relevance. Consequently, Palmer [8] examines the problems of public access to health services, social protection and security, the possibility of financial provision of these services through the prism of the European Convention on Human Rights and Fundamental Freedoms. A step-by-step approach to protecting economic rights remains problematic in the context of efficiency due to differences in national policies and administrative procedures in different countries. Judicial practice makes it possible to move from a rather formalistic approach to the protection of economic rights to a systematic approach to addressing social inequality [8]. However, such a transition is slow due to caution in transformation and judicial decision-making [6].

Leijten examines the specifics of the protection of social-economic rights in the countries of the Council of Europe and the case law of the European Court of Human Rights [9]. He proposes an innovative approach through the "core rights approach" to the decision of court decisions based on case law. "Case the case law of the European Court of Human Rights protects aspects of the right to work" [2]. Thus, despite the lack of legal norms that directly protect economic rights, the scientific literature substantiates the approaches, methods and ways of indirect protection of these rights through case law. "Article 8 can be used to protect the right to seek employment, while arts 6 and 8 can be used to combat unfair dismissal" [2].

At the same time, Fredman argues that case law does not provide a full transformation in the field of protection of economic rights, the European Court of Human Rights "a worrying tendency to revert unexpectedly to formal equality, as in relation to racial violence" [6]. "Litigation for social and economic rights is increasing in frequency and scope in several countries, and exhibits appealing attributes such as inclusiveness and deliberative quality" [10]. Therefore, there are still problems in protecting economic rights due to the usage of counter-majority approach by courts and difficulties in complying with procedural requirements.

Emphasis is on subsidiarity in connection with the reforms of the European Court of Human Rights, "the adoption of Protocol 15 to the European Convention on Human Rights, the Court is said to have entered an "age of subsidiarity" [11]. Nevertheless, the procedural tendency is traced through increase of requirements to processes in case law. The checks of procedural type are also used. As a result, the case law is based on a procedural approach, which is complex and requires the use of integrated and systematic approaches to the protection of economic rights, which integrate to form a "multifaceted approach" [11]. Some relevant studies can be found in [12] and [13].

Timmer's anti-stereotypical approach is seen as a way to overcome the problem of gender discrimination that exists because of stereotypes. "The proposed analysis consists of two phases: 'naming' and 'contesting' stereotypes" [1]. This approach can be used in judicial practice to protect the economic rights of different social groups.

Mantouvalou proposes a comprehensive approach based on the legal framework to the protection of economic rights, including labor rights. "Labor rights have been neglected in human rights law" [3]. An integrated approach involves the interpretation of human rights as social, economic, civil, political, labor in order to resolve contradictions in court decisions and take into account freedom as a key human value [3]. The integrated approach is effective because "The distinction between the two sets of rights - civil and political rights on the one hand, and social-economic rights on the other hand - has begun to fade" [14]. 
Strengthening the protection and support of economic rights is a central strategic task of governments and should take into account the current economic problems of all citizens. Achieving protection effectiveness in austerity conditions due to the 2008 crisis and macroeconomic discipline requires the use of a strategic approach $[7 ; 15]$.

\subsection{Research on the protection of economic rights in Eastern European countries}

Structural shifts as a result of economic reforms lead to the evolution of economic rights through the emergence of new social-economic relations, labor migration, budget constraints, liberalization, subsidy reductions and other factors [16]. During the transition period, the structure of the economy determines the social policy of countries, as happened in Eastern Europe after the fall of Communism [17].

Social protection measures contradict the market economy and at the same time complement market mechanisms. Problems of protection of social and economic rights are intensified in the conditions of formation of market conditions of management [18]. The issue of workflow automation is of primary importance for many developing countries because a large amount of funds is allocated, but not every process or service becomes effective and workers may lose their jobs [19]. Market integration and social protection in the conditions of transformation of Eastern European countries is a problematic issue, which involves the formation of a social market model of the economy to protect citizens in conditions of fierce competition.

For example, "EU has moved beyond a mere market - integration scheme - although the degree, to which it has done in such way, varies between markets and issue areas" [18]. Changing the political structure of Central and Eastern Europe has transformed the legal mechanisms for protecting citizens. EU legal system is the standard for Eastern European countries to follow [20]. The "gradual extension of the 'Western' integration project to Eastern Europe" leads to the import of EU practice in the field of protection of economic rights of citizens [21]. Ensuring a balance between economic development during the transition, the integration of Eastern European countries into EU and social development is a central issue. The problem of social dumping is seen as a serious threat to the protection of economic rights of citizens under the influence of neoliberal ideology [22].

"The European Court of Justice (ECJ), the European Court of Human Rights (ECtHR), and the European Free Trade Area (EFTA) Court successfully transformed the intergovernmental European Community (EC) treaties and the European Convention on Human Rights (ECHR) into constitutional orders founded on respect for human rights" [23].

Since the entry into force of the Treaty on European Union (TEU), European citizens have enshrined a number of legal rights and freedoms since 2009 [24]. Despite the developed system of protection of economic rights, the development of the social-economic system leads to new problems in this area: protection of cultural rights through cultural diversity and integration within Europe, protection of minorities [25]; copyright protection and piracy [26]; protection of personal data that become the subject of trade in the digital economy [27].

The specificity of the completeness of studying the problem of economic rights' protection in Eastern Europe lies in the economic and legal aspect. This issue is complex and serious and requires knowledge of both economic and legal nature at the present stage of economic development. The study of research in the field of protection of economic rights in Eastern Europe proves the lack of a thorough analysis of the main problems in this area.

\section{Methodology}

This study is based on the "multifaceted approach" [11], which combines:

1) an integrated approach [3] to the analysis of economic rights based on the analysis of the regulatory framework and statistical indicators;

2) a systematic approach to addressing the protection of economic rights [8] in Eastern Europe.

The study combines qualitative and quantitative methodologies. The case method was used to assess the legal aspect of the problems of protection of economic rights. Statistical data from Eastern European countries were used to study the economic aspect.

The research methodology includes methods of analysis and generalization of international business and human rights standards, analysis of mechanisms for protection of economic rights in Eastern Europe, research of human rights standards and recommendations in this area, analysis of statistical indicators to confirm violations of economic rights in Eastern European countries (Bulgaria, the Czech Republic, Hungary, Lithuania, Poland, Romania, Slovenia, Slovakia).

To confirm and form the main problems in the field of protection of economic rights, the cases of Eastern European countries were used in the following areas: 1) non-payment of salaries; 2) 
discrimination; 3) the impact of the polluted environment on human health; 4) violation of intellectual property rights.

The following data were used for analysis: GDP per capita, PPP (constant 2017 international \$) and Overall Gender Equality Index sub-indices. To show the relationship between economic rights violations and consequences for economic development, welfare and quality of life the Scatter plot was used.

\section{Results}

The first version of the Treaties establishing the European Communities made no mention of human rights or their protection. At the time, they did not even think that the creation of a European free trade area could have any impact on human rights. But when the European Court of Justice (ECJ) began to receive requests for human rights violations in the application of Community law, it created a system of legal rules known as the "General Principles of Community Law".

In the course of implementing their policies, EU and its member countries understood that this could have some impact on human rights. At the same time, they constantly tried to "bring" their citizens closer to EU. As a result, the Charter of Fundamental Rights of European Union was proclaimed in 2000. In 2009, following the entry into force of the Lisbon Treaty, EU Charter of Fundamental Rights became legally binding: all EU institutions are obliged to comply with its provisions.

This obligation also applies to EU member states, but only if they apply EU law. This restriction is clearly set out in the Protocol to the Charter for the Czech Republic, Poland and the United Kingdom. Since then, the citizens of European Union have taken a big step forward in terms of their legal rights and freedoms. The Lisbon Treaty now recognizes rights, freedoms and principles outside a simple market context, setting them out in the Charter of Fundamental Rights of European Union (EUCFR) and making the provisions of that Charter binding.

At the same time, all constitutions of Eastern Europe countries define the catalog of economic rights, in particular the right to property, which ensures human freedom, the material basis of its existence, rights related to labor relations (freedom of labor, the right to choose to work, prohibition of forced labor, decent wages, safe working conditions), etc.

The provisions of the UN Guiding Principles on Business and Human Rights, developed by the UN, are aimed at eliminating the inconsistency between the level of legal regulation of economic rights and the mechanism of their protection. The Council of
Europe adopted the Recommendations of the Committee of Ministers to member states on human and business rights of March 2, 2016. Legal regulation in EU countries and legal positions of judicial institutions indicate that the concept and mechanisms of protection of economic rights are changing and directly address the relevant requirements. Moreover, the direct addressee of the relevant requirements is not only the state but also business [28].

The UN Guiding Principles on Business and Human Rights include three principles: the state's obligation to protect human rights from violations by third parties, including business. Firstly, it presupposes the need to ensure the implementation of international human rights standards at the national level. Secondly, it is about the duty of business to respect human rights, which includes the need to be cautious about the possible negative impact of economic activity on human rights, in particular the rights of workers, consumers, the community, suppliers and so on. Thirdly, it provides effective remedies for both judicial and state and non-state extrajudicial.

At the same time, government obligations are to protect freedom of action and to protect resources from other, more aggressive parties (strong economic interests, fraud, unethical behavior in trade and in contractual relations, marketing and dumping). Herewith, the ways of realization of economic rights of the concrete country differ from model of economy. Consequently, in market economies, direct and indirect taxation are used to ensure equal opportunities.

In modern conditions, the main task of each state that wants to implement the UN Guidelines is to conduct a National Assessment of Basic Indicators in Business and Human Rights. It is necessary to assess the current level of implementation of recognized human rights standards by business in a particular country. This is an analysis of legal mechanisms, public policy, identification of the main forms and manifestations of the impact of business on human rights.

Such National Assessment of Business and Human Rights Baseline Indicators should cover the full range of economic, social, cultural, civil and political rights. For example, according to the report "Implementation of the UN Guiding Principles: The Case of the Czech Republic", published in December 2013 by representatives of Masaryk University, the impact of the UN Guiding Principles in the Czech Republic remains low.

Most of the top 30 companies (in terms of annual income) operating in the Czech Republic do not 
know about this document. Only five companies have met several UN Guidelines commitments. Two firms support them in some way and three seek to implement them, while two firms demonstratively do not do it.

Poland has not ratified any international treaty on economic, social and cultural rights, the rights of children and the rights of persons with disabilities. Such ratification would enable individuals or their organizations to look for the ways of protecting at the international level.

The arguments against the adoption of such agreements presented by the Polish Ministry of Foreign Affairs are quite unconvincing, in particular, regarding financial restrictions.

The Charter of Social Rights of the Council of Europe is the equivalent of the International Covenant on Economic, Social and Cultural Rights within a regional (European) human rights system. This generalized notion covers five international agreements:

1) European Social Charter (ESC) (18 October, 1961);

2) Additional Protocol to the European Social Charter (5 May 1988);

3) Protocol amending the European Social Charter (21 October 1991);
4) Additional Protocol to the European Social Charter, providing for a system of collective complaints (9 November 1995),

5) Revised European Social Charter (3 May 1996).

The Republic of Poland is a party to the European Social Charter and the Protocol Amending the European Social Charter as of 21 October 1991. On 25 October 2005, Poland also signed the Revised European Social Charter, which is still awaiting ratification.

The following are typical violations of economic rights in Eastern Europe.

\subsection{Non-payment of salaries}

One of the main directions of the European Social Charter (revised) is to ensure the right to protection against poverty and social exclusion.

The poor in EU are people whose total income (including social benefits) is less than $60 \%$ of the national average indicator. According to Eurostat data, indicators on living conditions and poverty (Table 1) and fair working conditions (Dynamic labor markets and fair working conditions - Table 2) determine equal opportunities and access to the labor market as indicators of social-economic human rights.

Table 1. Living conditions and poverty, 2019 (\%)

\begin{tabular}{|l|c|c|c|c|c|c|c|c|}
\hline $\begin{array}{l}\text { Geographic region } \\
\text { Poverty rate }\end{array}$ & Bulgaria & $\begin{array}{c}\text { The Czech } \\
\text { Republic }\end{array}$ & Hungary & Lithuania & Poland & Romania & Slovenia & Croatia \\
\hline $\begin{array}{l}\text { People at risk of } \\
\text { poverty or social } \\
\text { exclusion }\end{array}$ & 32.5 & 12.5 & 18.9 & 26.3 & 18.2 & 31.2 & 14.4 & 23.3 \\
\hline $\begin{array}{l}\text { At-risk-of-poverty } \\
\text { rate }\end{array}$ & 22.6 & 10.1 & 12.3 & 20.6 & 15.4 & 23.8 & 12.0 & 18.3 \\
\hline $\begin{array}{l}\text { Severe material } \\
\text { deprivation rate }\end{array}$ & 19.9 & 2.7 & 8.7 & 9.4 & 3.6 & 14.5 & 2.6 & 7.2 \\
\hline $\begin{array}{l}\text { People living in } \\
\text { households with very } \\
\text { low work intensity } \\
\text { population aged 0 to } \\
59 \text { years) }\end{array}$ & 9.3 & 4.2 & 5.0 & 7.5 & 4.7 & 6.0 & 5.2 & 9.2 \\
\hline
\end{tabular}

Consequently, $32,5 \%$ of the population of Bulgaria in 2019 were at risk of poverty and/or social exclusion, ranking first among EU member states of the Eastern Bloc (Table 1). Of these, $22,6 \%$ of Bulgarians lived below the poverty line. The reason for this, among other factors, is the relatively high (compared to other countries) share of the unemployed $(4,2 \%)$ among the economically active population $(73,2 \%$ (Table 2$)$ ). A similar relationship is observed in Lithuania, where the risk of poverty is $20,6 \%$, combined with an unemployment rate of $6,3 \%$, and in Romania $(23,8 \%$ and $3,9 \%$, respectively) (Tables 1 and 2).

Adequate standard of living is determined by the level of the minimum wage in the country. The level of the minimum wage in Eastern Europe can be divided into three groups depending on EU accession. 
Table 2. Dynamic labour markets and fair working conditions, 2019 (\%)

\begin{tabular}{|c|c|c|c|c|c|c|c|c|}
\hline $\begin{array}{l}\text { Geographic region } \\
\text { Unemployment rate }\end{array}$ & Bulgaria & $\begin{array}{l}\text { The Czech } \\
\text { Republic }\end{array}$ & Hungary & Lithuania & Poland & Romania & Slovenia & Croatia \\
\hline $\begin{array}{l}\text { Economic activity } \\
\text { rates (from } 15 \text { to } 64 \\
\text { years) }\end{array}$ & 73.2 & 76.7 & 72.6 & 78.0 & 70.6 & 68.6 & 75.2 & 66.5 \\
\hline $\begin{array}{l}\text { Unemployment rates } \\
\text { (from } 15 \text { to } 74 \text { years) }\end{array}$ & 4.2 & 2.0 & 3.4 & 6.3 & 3.3 & 3.9 & 4.5 & 6.6 \\
\hline $\begin{array}{l}\text { Youth unemployment } \\
\text { rate (from } 15 \text { to } 24 \\
\text { years) }\end{array}$ & 8.9 & 5.6 & 11.4 & 11.9 & 9.9 & 16.8 & 8.1 & 16.6 \\
\hline
\end{tabular}

The lowest minimum wages in the second half of 2020 (less than $€ 500$ per month) are in Bulgaria ( $€$ 312 ), Hungary ( $€$ 452) and Romania (€ 461) (see Fig.1). These countries, except for Hungary, joined EU in 2007. The countries of the Eastern bloc of the first wave of accession to EU (2004) - Poland, Slovakia, and the Czech Republic form an average group with a minimum wage of $€ 500$ to $€ 600$ per month. This group also includes Croatia ( $€$ 537), which is the country of the third wave of accession to EU (2013). Slovenia ( $€ 941$ euros) is the only new EU member state to form a group with a minimum wage of around $€ 1000$. For comparison, in Western Europe this figure is more than $€ 1500$ euros: in Belgium - $€ 1$ 625, in Germany - $€ 1$ 584, in France $€ 1539$ per month.

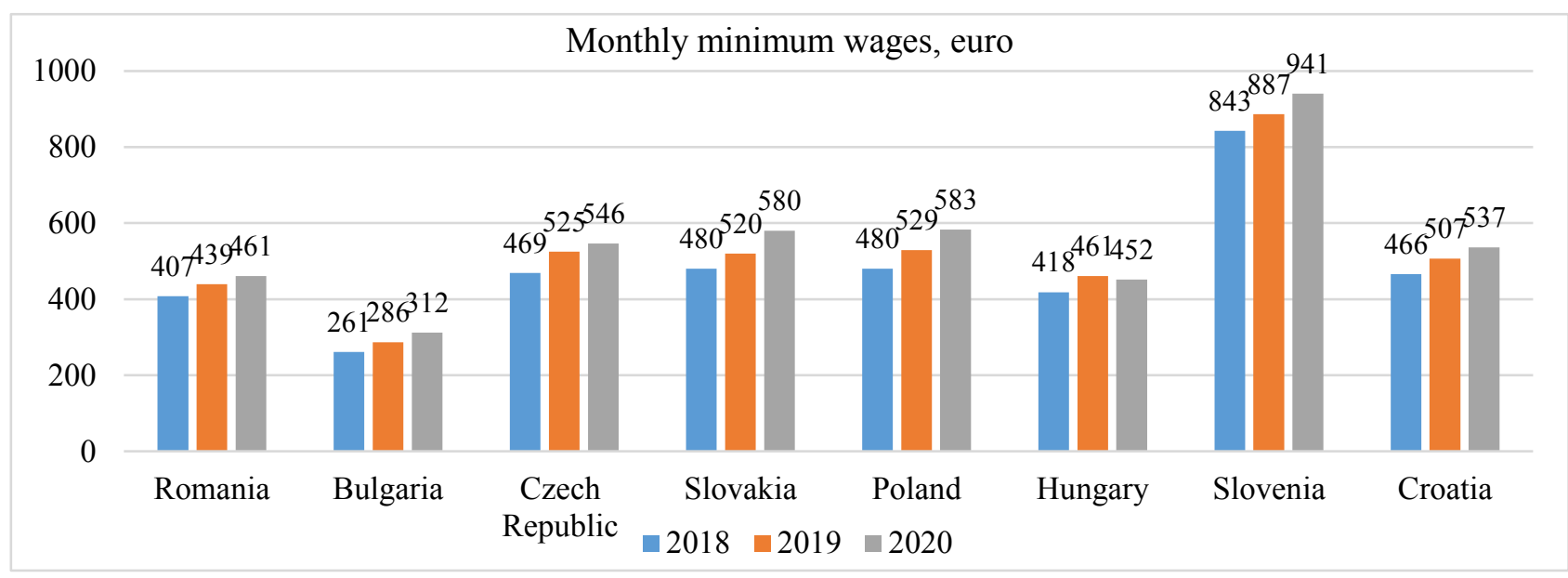

Fig.1. Comparison of the minimum wage in Eastern European countries

After the financial crisis of 2008 and austerity, non-payment of salaries as a global problem in the field of workers' rights began to increase. This leads to new problems - the needs of the population to strengthen social security, the need to protect the rights of workers and go to court. "Improving the protection of the most vulnerable and marginalized segments of the population,... the rights to access to courts, to housing or to social security have further gained in relevance and importance" [7]. This problem proves the importance of an integrated approach to the protection of economic rights, because the violation of one right (to pay for work) causes a number of other violations.

In September 2013, employees of the Nairit rubber factory protested for unpaid salaries, which they did not receive for an average of 10-12 months. In November 2013, Georgian unions won an "important victory" over the leadership of the Georgian
Railways, which supposedly refused to negotiate overtime pay, a fair system of bonuses and bonuses for years of service and qualifications, which led to a strike of about 6000 workers. Only after all these events the employer agreed to start the negotiations and an agreement was reached. In December 2013, the Bulgarian Labor Inspectorate registered almost 124000 violations of labor legislation between June and November 2013. Non-payment or delay of salary was one of the most serious problems in the relationship between an employer and an employee. In March 2014, hundreds of irrigation workers protested against 4 months of unpaid wages in Bulgaria [29].

\subsection{Discrimination in the labor market}

According to the directives of European Union, nondiscrimination is an independent right, but it is limited to a certain context, in particular the context 
of employment relations. The institutions of European Union are obliged to abide by the Charter of Fundamental Rights of European Union, including the provisions on non-discrimination. In addition, EU Member States are obliged to comply with the provisions of the Charter when applying the provisions of Community law.

At the same time, Roma continues to be discriminated against throughout Europe, including in Eastern Europe. In the Czech Republic, an analysis of job applications by the CERGEEI academic institute showed that a non-Roma applicant is $75 \%$ more likely to be invited to work than a Roma applicant.

In Hungary, Roma's wages are lower than the Hungarian minimal salary. In Bulgaria, $82 \%$ of Roma, working in the construction and textile sectors, complain that they are employed in lowerpaid positions, and 38,6\% complain about receiving lower wages compared to Bulgarians who do the same work.

In the Czech Republic, respondents said they were denied promotion, explaining that "it's not time for a "black man" to work in a managerial position". In Bulgaria, a survey conducted by the Open Society Institute found that few respondents agreed to accept a migrant on the board of the company in which they work.

In Eastern Europe as a whole, there are a number of opportunities to address discrimination against minorities, along with dilemmas related to EU action in this area. The integration of scrutiny models and the protection of the economic rights of minorities needs to be improved [23].

Another problem in the field of discrimination is the illegal dismissal of migrant workers. A Polish study on the practice of imminent dismissal concluded that in many cases they were migrant workers who were forced to work overtime under the threat of dismissal.
In Lithuania, $43,8 \%$ of national minorities said they faced discrimination in employment or in the workplace. $45,9 \%$ of women from national minorities and $16,8 \%$ of men from national minorities stated that access to the labor market is one of the main problems they face in the employment sector. National minorities stated that discrimination in access to work was linked to discrimination in wages and working conditions. In Slovakia, migrants are often forced to accept work with a lower level of legal protection, lower salaries and no career prospects or employment stability.

However, modern jurisprudence indicates that the European Court of Human Rights has taken a stronger position on guarantees of equality in accordance with Articles 14 of the European Convention for the Protection of Human Rights and Fundamental Freedoms [6]. Nevertheless, not only in Eastern Europe, but in the world as a whole, there is no consistent concept of ensuring equality regardless of the social-economic characteristics of the citizen. Judicial practice remains quite careful in sentencing and there are cases of return to formal equality [6].

Although the principle of equal pay for equal work is enshrined in European Treaties (Article 157 TFEU since 1957), in some cases women receive lower wages than men for the equivalent amount of work performed [30]. In Eastern European countries (Table 3), the Overall Gender Equality Index shows a significant gender gap by country: the largest gender gap is in Hungary $(51,9)$, Romania $(54,5)$, Poland $(55,2)$ and Lithuania $(55,5)$. The reasons for discrimination against women are, in particular, sectoral segregation (employment of women in lowwage sectors), imbalance between personal life and career, certain position in the hierarchy. The biggest difference is observed in the salaries of women managers - within EU, salaries are $23 \%$ lower than for men $[30 ; 31]$.

Table 3. Gender Equality Index scores, domain scores and sub-domain scores, 2017

\begin{tabular}{|l|c|c|c|c|c|c|c|c|}
\hline $\begin{array}{l}\text { Geographic region\(Sub-) } \\
\text { Domain Scores }\end{array}$ & Bulgaria & $\begin{array}{c}\text { The Czech } \\
\text { Republic }\end{array}$ & Hungary & Lithuania & Poland & Romania & Slovenia & Slovakia \\
\hline $\begin{array}{l}\text { Overall Gender Equality } \\
\text { Index }\end{array}$ & 58,8 & 55,7 & 51,9 & 55,5 & 55,2 & 54,5 & 68,3 & 54,1 \\
\hline Work (Domain score) & 69 & 67 & 67,4 & 73,6 & 67 & 67,7 & 73,3 & 66,5 \\
\hline $\begin{array}{l}\text { Participation in work } \\
\text { (Subdomain score) }\end{array}$ & 83,5 & 83,5 & 81 & 89,7 & 80,2 & 79 & 86,5 & 82,6 \\
\hline $\begin{array}{l}\text { Segregation and quality of } \\
\text { work (Subdomain score) }\end{array}$ & 57 & 53,7 & 56 & 60,4 & 56 & 58 & 62,1 & 53,5 \\
\hline Money (Domain score) & 61,8 & 76,7 & 71,6 & 64,7 & 75,1 & 62 & 82,4 & 74,2 \\
\hline $\begin{array}{l}\text { Financial resources } \\
\text { (Subdomain score) }\end{array}$ & 50,2 & 59,8 & 55,5 & 55 & 62,8 & 47,2 & 70 & 56,8 \\
\hline $\begin{array}{l}\text { Economic situation } \\
\text { (Subdomain score) }\end{array}$ & 76,1 & 98,2 & 92,5 & 76,1 & 89,9 & 81,6 & 97,1 & 96,9 \\
\hline
\end{tabular}




\begin{tabular}{|c|c|c|c|c|c|c|c|c|}
\hline Knowledge (Domain score) & 53,2 & 59 & 56,9 & 55,9 & 56,5 & 51,5 & 56 & 60,4 \\
\hline $\begin{array}{lr}\text { Attainment } & \text { and } \\
\text { participation } & \text { (Subdomain } \\
\text { score) } & \\
\end{array}$ & 55,4 & 69,9 & 63,4 & 69,4 & 61,5 & 52,4 & 66,9 & 59,7 \\
\hline $\begin{array}{l}\text { Segregation } \\
\text { score) }\end{array}$ & 51 & 49,8 & 51 & 45 & 51,9 & 50,7 & 46,9 & 61,1 \\
\hline Time (Domain score) & 42,7 & 57,3 & 54,3 & 50,6 & 52,5 & 50,3 & 72,9 & 46,3 \\
\hline $\begin{array}{l}\text { Care activities (Subdomain } \\
\text { score) }\end{array}$ & 55,7 & 56,8 & 65 & 64 & 64,1 & 70,7 & 69,5 & 56,5 \\
\hline $\begin{array}{l}\text { Social activities } \\
\text { (Subdomain score) }\end{array}$ & 32,6 & 57,7 & 45,4 & 40 & 43 & 35,8 & 76,4 & 37,9 \\
\hline Power (Domain score) & 59,9 & 26,1 & 20,6 & 32,5 & 29,1 & 38,8 & 57,6 & 26,8 \\
\hline $\begin{array}{ll}\text { Political } & \text { power } \\
\text { (Subdomain score) } & \\
\end{array}$ & 53,8 & 37,8 & 15 & 40,9 & 43,6 & 40,8 & 67,3 & 35,3 \\
\hline $\begin{array}{ll}\text { Economic } & \text { power } \\
\text { (Subdomain score) }\end{array}$ & 59,9 & 13,6 & 23,1 & 18,5 & 33,1 & 20,5 & 50,4 & 17,9 \\
\hline $\begin{array}{l}\text { Social power (Subdomain } \\
\text { score) }\end{array}$ & 66,8 & 34,3 & 25,1 & 45,3 & 17 & 69,7 & 56,2 & 30,4 \\
\hline Health (Domain score) & 77,1 & 86,3 & 86,6 & 79,8 & 83,2 & 71,1 & 87,1 & 85,8 \\
\hline $\begin{array}{l}\text { Health status (Subdomain } \\
\text { score) }\end{array}$ & 89 & 90 & 86,6 & 80 & 87,3 & 88,6 & 89,4 & 88,1 \\
\hline $\begin{array}{l}\text { Healthy behaviour } \\
\text { (Subdomain score) }\end{array}$ & 52,3 & 72,3 & 76,8 & 64,8 & 67,9 & 42,5 & 75,9 & 73,1 \\
\hline $\begin{array}{l}\text { Access to health structures } \\
\text { (Subdomain score) }\end{array}$ & 98,5 & 98,7 & 97,6 & 98,2 & 97 & 95,7 & 97,5 & 98 \\
\hline
\end{tabular}

Eastern European countries are characterized by differences depending on the component of gender inequality. In Bulgaria, the largest gender gap can be traced by the sub-index of social activity $(32,6)$ and time (42,7). In the Czech Republic, Lithuania, Slovakia, the largest gap can be seen in the sub-index of economic impact $(13,6,18,5$ and 17,9) and power $(26,1,32,5$ and 26,8). In Hungary, the lowest subindices are political force (15) and power $(20,6)$.

In Poland, the greatest gender inequality is manifested in the sphere of women's influence and social influence (29,1 and 17). In Romania, women suffer the most from inequalities in the sub-indices of economic strength and social activity $(20,5$ and 35,8$)$. In Slovenia, problems with gender inequality are most pronounced in the areas of segregation and economic influence $(46,9$ and 50,4). At the same time, there is almost no gap between women and men in the Access to health structures subdomain for all Eastern European countries.

It can be traced that Slovenia with the highest level of Overall Gender Equality Index (See Fig. 2) has the highest value of GDP per capita, PPP. The same feature is characteristic of the Czech Republic and Lithuania.

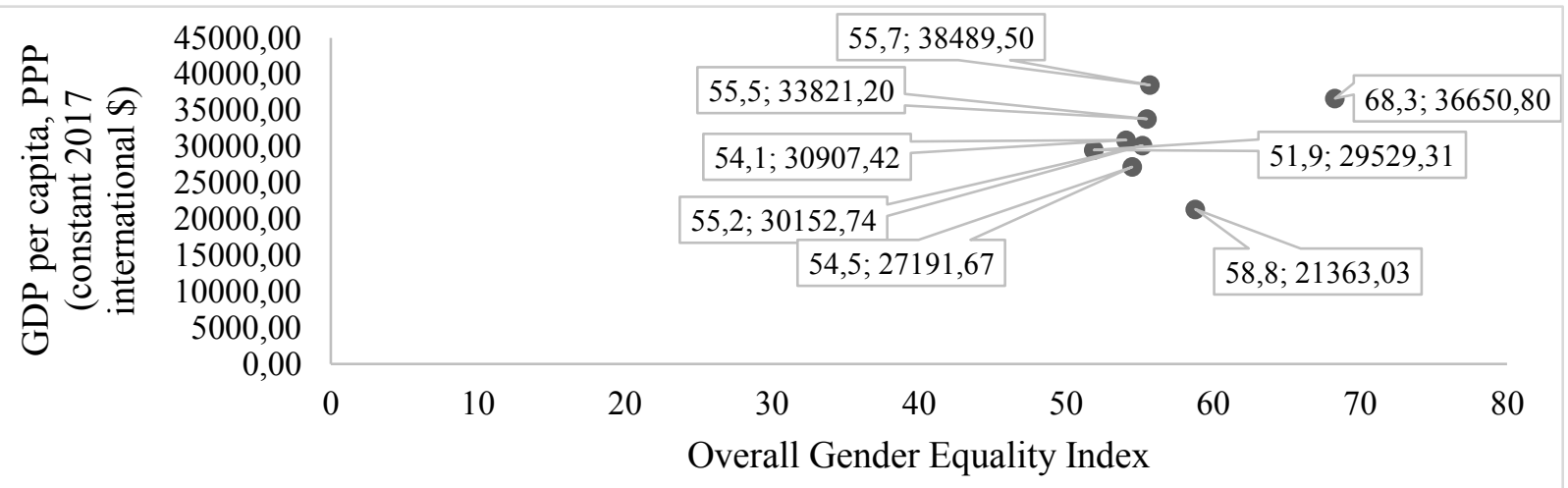

Fig. 2. GDP per capita, PPP (constant 2017 international \$) dependence from Overall Gender Equality Index in Eastern Europe, 2017 
However, despite the high value of the Overall Gender Equality Index, Bulgaria has the lowest level of GDP per capita, PPP [31;32]. This may be due to the relatively high level of influence of women in the political, economic, social spheres $(53,8,59,9$ and $66,8)$ with the simultaneous low sub-indices in the possession of financial resources $(50,2)$, knowledge $(53,2)$, segregation (51) and social activity. For comparison, in Slovenia women have a lower level of economic and social influence.

Therefore, the lack of consistent application of the case law by Eastern European countries is an obstacle to eliminating discrimination, in particular against women in all areas of the economy and politics. Structural changes in the economy in these countries are not complete, the process of convergence to developed countries is continuing. As a result, Eastern Europe is in the process of transforming and integrating economic rights practices.

\subsection{Infringement of intellectual property rights}

Enforcement of intellectual property rights is extremely important for the functioning of the market mechanism in today's economy, which is based on trade in services and software products. Most Central and Eastern European countries have already had intellectual property rights and protection systems. However, the law enforcement mechanism in a number of countries still needs to be strengthened.

The Court of Justice has ruled that the Intellectual Property Protection Directive (2004/48/EC) does not prevent EU member states from adopting legislation providing for penalties for infringements of intellectual property. The Directive requires member states to apply the measures, procedures and remedies necessary to ensure intellectual property rights.

Such measures shall be fair, proportionate and should not create barriers to legitimate trade and have to provide protection against their abuse. For example, the Polish copyright licensing authority SO filed a lawsuit against SF cable broadcaster, which distributed television programs containing copyrighted works in Poland without the consent of the copyright holder.

A Polish court has applied to EU with the issue whether the Directive prevents Member States from adopting legislation that requires, as an alternative, the payment of a fixed amount of damages equivalent to twice the hypothetical amount of royalties. EU has ruled that Polish law complies with the Directive, even if it does not oblige the rightsholder to prove their actual loss or any causal link between the violation and that loss.
It is interesting that the EU did not follow the Advocate General's view that Polish law ignores the principle that compensation should be commensurate with the caused damage. Instead, it chose a measure that is punishable rather than compensatory. As a result of this decision, Member States may enact laws providing for compensation equivalent to a multiple of the cost of the license fee for the lawful use of intellectual property [33].

On January 16, 2020, the Economist Intelligence Unit developed a report on Poland on the prospects of economic development, economic and political trends and corporate practice for 2020-2024. According to the report, consumption growth is projected in 2020 , projected at $3,8 \%$ annually, an increase in government payments to families and retirees, as well as the introduction of new tax benefits. In 2021-24 labor shortages are projected, which will affect production capacity

\subsection{Impact of the polluted environment on human health}

Reports of harmful effects of polluted air, water and land on human health remain very frequent nowadays. This applies to the extractive and energy spheres. In May 2013, thousands of Romanians protested Chevron's plans to search for shale gas due to environmental and health concerns. Chevron said all his activities "meet the norms of Romanian law, EU requirements and strict industry standards".

However, in October 2013, Chevron said that the company had decided to stop searching for shale gas in Romania after protests continued across the country. In December 2013, Chevron resumed shale gas exploration in northeastern Romania after hundreds of riot police brutally evacuated villagers protesting the company's plan. About 40 people were beaten and arrested. Chevron determined that these activity priorities were safety and environmental responsibility.

\section{Discussion}

The populations of Europe, citizens of European Union (EU), have significantly strengthened legislation in the field of securing legal rights and freedoms [24]. As the present study has revealed, the countries of Eastern Europe (Slovenia, the Czech Republic and Lithuania) have significantly reduced gender inequality. However, case law does not guarantee full protection of fundamental economic rights, and certain groups of the population have to seek protection of rights through the application of Community treaties [24]. 
In developing countries, as well as in advanced countries public support for economic rights is still limited, including due to political animosity and media coverage [15]. The present research confirms similar findings of Bell \& Cemlyn [15], forasmuch as they reveal different examples of discrimination of economic rights in Poland, Romania, Slovenia and other countries of Eastern Europe with different levels of economic development. The issue of how to increase public support for the practice and principles of protecting economic human rights remains. The solution may lie in shifting the focus of the discourse on citizens' rights, taking into account the various daily concerns and problems in this area in the public of different countries of Eastern Europe. Particular attention is paid to economic rights; it is relevant due the need to improve the quality of life in Eastern European countries [15]. Such strategy is relevant in the context of austerity in terms of mobilizing support for human rights.

On the other hand, the strengthening of the protection of the economic rights of certain groups of the population can increase the contradictions that exist between a sovereign state, human rights and citizenship. An example of such contradiction is the protection of the rights of illegal migrants in the field of health [5]. In order to address such gaps, it is necessary to conduct a vulnerability analysis of different population groups to improve the health protection standards of illegal migrants.

A specific feature of social and economic rights is that not all of them can be protected in court. As it has been noted [3], there is "uncertainty in judicial decision-making" in case law. This is due to the lack of a comprehensive approach to the interpretation of social, in particular, labor rights, as well as the lack of effective mechanisms to ensure the protection of social-economic rights in international human rights law [14].

Investigations of Fredman have revealed that the European Court of Human Rights remains cautious about transforming case law in such contexts: "complementary goals of eliminating disadvantage (distributional dimension), eliminating stereotypes, prejudices, humiliation and violence (measurement of recognition), promotion of participation (participatory dimension); and adjustment to differences, including through structural change (transformative aspect)" [6]. This leads to formal equality when there are practical examples of violations of the economic rights of citizens. In the countries of Eastern Europe, the lack of a transforming aspect is especially revealed: formally, states ensure the strengthening of the institution of protecting economic rights; however, practice indicates the presence of a number of violations.

Thus, while there are gaps in legislation and case law in terms of protecting economic rights, citizens remain vulnerable to different stereotypes, violence, prejudice and humiliation [1]. First of all, the present research confirms the conclusions of other scientists on the examples of violation of the economic rights of women (Bulgaria), discrimination against national minorities (Lithuania), protection of intellectual property rights (Poland) and other examples. In Eastern European countries, vulnerabilities in the protection of the economic rights of women and children, migrants and minorities are especially increased during the crisis [4]. This study shows that countries with lower levels of equality have lower levels of quality of life.

\section{Conclusion}

The issue of protection of economic rights in Eastern Europe is intensifying. In addition to the unresolved issues of non-payment of salaries and discrimination against various social groups, these countries are facing new challenges in the field of protection of intellectual property rights through the development of the digital economy. The legal system carefully and slowly integrates the practice of developed countries to provide guarantees for the most vulnerable citizens (women, migrant workers).

As a result, Eastern European countries are characterized by slow structural changes in the economy and an average level of GDP per capita. The EU set up a general framework for equal treatment in employment and occupation, empowering it to combat discrimination based on religion or belief, age, disability and sexual orientation on the labour market. But discrimination is still one of the basic problems; it is characterized by differences and does not ensure equal rights for potential employees. The revealed connection between gender equality and the economic well-being of the population proves the importance of protecting economic rights as a tool to ensure the formation of a socially-oriented market economy and can be used for future research.

In general, the problem of protection of economic rights remains relevant in Eastern Europe. Its solution requires cooperation and contractual regulation between states in the field of protection of economic rights and ensuring access to judicial and extrajudicial protection mechanisms, in particular to ombudsmen. Along with this, in Eastern Europe, the institution of ombudsmen is being transformed from an administrative oversight body into a state body for human rights protection and human rights monitoring, taking into account international 
standards, which requires further research in this area.

\section{References:}

[1] Timmer, A., Toward an anti-stereotyping approach for the European Court of Human Rights. Human Rights Law Review, 11 (4), 2011, pp. 707-738. https://doi.org/10.1093/hrlr/ngr036

[2] O'Connell, R., The Right to Work in the ECHR. EUR. HUM. RTS. L. REV., 2, 2012, pp. 176-176.

[3] Mantouvalou, V., Labour Rights in the European Convention on Human Rights: An Intellectual Justification for an Integrated Approach to Interpretation. Human Rights Law Review, 13(3), 2013, pp. 529-555.

[4] Qerimi, Q., \& Sergi, B. S., The nature and the scope of the global economic crisis' impact on employment trends and policies in South East Europe. Journal of International Studies, 10(4). 2017, pp. 143-153. Retrieved from https://www.ceeol.com/search/articledetail $?$ id $=607115$

[5] Da Lomba, S., Vulnerability, irregular migrants' health-related rights and the European Court of Human Rights. European journal of health law, 21(4), 2014, pp. 339-364. https://doi.org/10.1163/15718093-12341325

[6] Fredman, S. (2016). Emerging from the shadows: Substantive equality and article 14 of the European convention on human rights. Human Rights Law Review, 16(2), 273301. https://doi.org/10.1093/hrlr/ngw001

[7] Tulkens, F. (2013). The European Convention on Human Rights and the economic crisis: the issue of poverty. Retrieved from http://hdl.handle.net/1814/28099

[8] Palmer, E. (2009). Protecting Socio-Economic Rights Through the European Convention on Human Rights. Erasmus Law Review, 2(4), 397-425. Retrieved from http://hdl.handle.net/1765/20576

[9] Leijten, I. (2018). Core socio-economic rights and the European Court of Human Rights. Cambridge University Press.

[10] Gauri, V., \& Gloppen, S. (2012). Human rightsbased approaches to development: Concepts, evidence, and policy. Polity, 44(4), 485-503. https://doi.org/10.1057/pol.2012.12

[11] Huijbers, L. M. (2017). The European Court of Human Rights' procedural approach in the age of subsidiarity. Cambridge International Law Journal, 6(2), 177-201. https://doi.org/10.4337/cilj.2017.02.05
[12] Holovatyi， M. (2014). Multiculturalism as a means of nations and countries interethnic unity achieving. Economic Annals-XXI, 11-12, 15-18.

[13] Shvets, V. Y., Rozdobudko, E. V., \& Solomina, G. V. (2013). Aggregated methodology of multicriterion economic and ecological examination of the ecologically oriented investment projects. Naukovyi Visnyk Natsionalnoho Hirnychoho Universytetu, 3, 139-144.

[14] Volou, A. (2017). The Protection of SocioEconomic Rights Through the Canon of Civil and Political Rights: A Comparative Perspective. Groningen Journal of International Law, 5(2), Retrieved from https://ssrn.com/abstract=3122099

[15] Bell, K., \& Cemlyn, S. (2014). Developing public support for human rights in the United Kingdom: reasserting the importance of socioeconomic rights. The International Journal of Human Rights, 18(7-8), 822-841. https://doi.org/10.1080/13642987.2014.951339

[16] Sachs, J., Woo, W., Fischer, S., \& Hughes, G. (1994). Structural Factors in the Economic Reforms of China, Eastern Europe, and the Former Soviet Union. Economic Policy, 9(18), 102-145. doi:10.2307/1344459

[17] Cerami, A., \& Vanhuysse, P. (2009). PostCommunist Welfare Pathways: Theorizing Social Policy Transformations in Central and Eastern Europe. Palgrave Macmillan. https://doi.org/10.1057/9780230245808_4

[18] Claassen, R., Gerbrandy, A., Princen, S., \& Segers, M. (2019). Four models of protecting citizenship and social rights in Europe: conclusions to the special issue 'rethinking the European social market economy'. JCMS: Journal of Common Market Studies, 57(1), 159174.

[19] Aleinikova O. , Kravchenko S., Hurochkina V., Zvonar V., Brechko O., and Buryk Z. (2020). Project Management Technologies in Public Administration. Journal of Management Information and Decision Sciences 23(5), 564576.

[20] Láng, I. (2005). Sustainable Development - A New Challenge for the Countries in Central and Eastern Europe. Hens L., Nath B. (eds) The World Summit on Sustainable Development. Springer, Dordrecht. https://doi.org/10.1007/14020-3653-1 9

[21] Pentassuglia, G. (2001). The EU and the protection of minorities: the case of Eastern Europe. European Journal of International 
Law, 12(1),

3-38.

https://doi.org/10.1093/ejil/12.1.3

[22] Rys, V. (2001). Transition countries of central Europe entering the European Union: Some social protection issues. International Social Security Review, 54(2- 3), 177-189. https://doi.org/10.1111/1468-246X.00098

[23] Petersmann, E. U. (2008). Human rights, international economic law and 'constitutional justice'. European Journal of International Law, 19(4),

769-798. https://doi.org/10.1093/ejil/chn041

[24] Blanke, H. J. (2012). The protection of fundamental rights in Europe. In The European Union after Lisbon (pp. 159-232). Springer, Berlin, Heidelberg. https://doi.org/10.1007/9783-642-19507-5_7

[25] Donders, Y. (2003). The Protection of Cultural Rights in Europe: None of the EU's Business?. Maastricht journal of European and comparative law, 10(2), 117-147. https://doi.org/10.1177\%2F1023263X0301000 202

[26] Andrés, A. R. (2006). The relationship between copyright software protection and piracy: Evidence from Europe. European Journal of Law and Economics, 21(1), 29-51. https://doi.org/10.1007/s10657-006-5670-5

[27] Costa-Cabral, F., \& Lynskey, O. (2017). Family ties: the intersection between data protection and competition in EU Law. Common Market Law Review, 54(1), 11-50. Retrieved from http://www.kluwerlawonline.com/toc.php?pubc ode $=$ COLA
[28] Office of the United Nations Commissioner for Human Rights (2020). Special Representative of the Secretary-General on human rights and transnational corporations and other business enterprises. Retrieved from https://www2.ohchr.org/english/issues/trans_co rporations/docs/

[29] Business and Human rights Resource Center (2014). Workers and Minorities Bear the Brunt of Abuse. Business \& Human Rights in Eastern Europe \& Central Asia May 2014. Retrieved from https://media.businesshumanrights.org/media/documents/files/media/ documents/eeca-regional-briefing-may2014.pdf

[30] European Commission (2020). The gender pay gap situation in the EU. Retrieved from https://ec.europa.eu/info/policies/justice-andfundamental-rights/gender-equality/equalpay/gender-pay-gap-situation-eu_en

[31] EIGE (2020). Gender Equality Index scores, domain scores and sub-domain scores [index_data_index_scores]. Retrieved from https://eige.europa.eu/gender-equality-index

[32] World Bank (2020). GDP per capita, PPP (constant 2017 international \$). Retrieved from https://data.worldbank.org/indicator/NY.GDP.P CAP.PP.KD

[33] Horton, A. (2017). IP Enforcement Directive: damages for infringement. Retrieved from https://www.twobirds.com/en/news/articles/201 7/uk/it-and-ip-law-bytes/ip-enforcementdirective-damages-for-infringement

\section{Creative Commons Attribution License $\quad 4.0$ (Attribution 4.0 International , CC BY 4.0)}

This article is published under the terms of the Creative Commons Attribution License 4.0 https://creativecommons.org/licenses/by/4.0/deed.en US 